\title{
RONGGA MULUT SEBAGAI RESERVOIR POTENSIAL UNTUK INFEKSI Pseudomonas aeruginosa
}

\author{
Puspita Hajardhini*, Heni Susilowati**, Heribertus Dedy Kusuma Yulianto***
}

${ }^{*}$ Prodi Magister Ilmu Kedokteran Gigi- Biologi Oral, Fakultas Kedokteran Gigi, Universitas Gadjah Mada

**Departemen Biologi Oral, Fakultas Kedokteran Gigi, Universitas Gadjah Mada

${ }^{* * *}$ Departemen Biomedika, Fakultas Kedokteran Gigi, Universitas Gadjah Mada

Correspondence : Puspita Hajardhini, Prodi Magister Ilmu Kedokteran Gigi- Biologi Oral, Fakultas Kedokteran Gigi, Universitas Gadjah Mada

Email : fitridiahoktadewi@gmail.com

\section{Keywords:}

biofilm, Pseudomonas aeruginosa, reservoir

\section{ABSTRACT}

Introduction : Pseudomonas aeruginosa ( $P$. aeruginosa) is Gram-negative bacteria which is normally inhabiting in environment, however it tends to be an opportunistic pathogen within oral cavity. It utilizes the oral cavity as potential reservoir to infect either lungs or oral cavity itself. Both planktonic and biofilm forms can mediate its infection in oral cavity so that making its difficulties to eradicate since its broad resistance to antibiotics.

Method : We review the pathogenesis of oral infection and host defense mechanism to P. aeruginosa as well.

Discussion: Several prevention strategies, both chemical and nonchemical, are elaborated to avoid oral bacterial contamination.

Conclusion : Prevention strategies in dental aspect to $P$. aeruginosa is highly needed as its occurrence are susceptible to cross-infection.

\section{PENDAHULUAN}

Pseudomonas aeruginosa ( $P$. aeruginosa) merupakan bakteri Gram-negatif yang mudah ditemukan di lingkungan namun bersifat patogen oportunistik yang secara umum menginfeksi pasien imunokompromis atau pasien rawat inap rumah sakit. Target koloni bakteri $P$. aeruginosa menyerang saluran pernapasan atas, terutama paru-paru sehingga menyebabkan pneumonia yang berpotensi mengakibatkan kematian. ${ }^{1}$ Bakteri harus melewati berbagai daerah anatomis rongga mulut untuk dapat berkoloni di paru-paru. ${ }^{2,3}$ Koloni bakteri pada rongga mulut dipermudah dengan buruknya kondisi kebersihan rongga mulut yang memicu terbentuknya biofilm atau melalui infeksi periodontal. ${ }^{4}$ Bakteri ini sering ditemukan pada biofilm rongga mulut yang terbentuk di permukaan gigi supragingival, subgingival, mukosa oral, dan dorsum lidah. ${ }^{2,3,5}$
Infeksi $P$. aeruginosa di rongga mulut jarang ditemukan, namun pada beberapa kasus dilaporkan terkait dengan kontaminasi bakteri ini melalui biofilm yang terbentuk di dental unit waterlines (DUWLs) dan prosedur dental. ${ }^{6-8}$ Rongga mulut memberikan proteksi melalui komposisi mikroorganisme yang seimbang, oleh karena itu adanya kondisi imunokompromis pada hospes yang dipicu oleh berbagai faktor sangat berpotensi mempermudah kolonisasi dan menimbulkan infeksi terhadap kesehatan rongga mulut dan sistemik.6,9 Keterlibatan P.aeruginosa dalam infeksi menunjukkan pergeseran komposisi bakteri lainnya pada rongga mulut. ${ }^{9}$ Terlebih lagi bakteri ini memiliki tingkat resistensi tinggi terhadap berbagai antibiotik sehingga menyulitkan eradikasi. ${ }^{10}$ Ditemukannya koloni bakteri ini di rongga mulut dengan target infeksi di paru-paru memunculkan kemungkinan 
peranan rongga mulut sebagai reservoir yang potensial untuk infeksi $P$. aeruginosa. ${ }^{3}$

Review ini membahas berbagai kemungkinan mekanisme masuknya $P$. aeruginosa melalui rongga mulut sebagai reservoir, potensi untuk menimbulkan infeksi baik di rongga mulut dan relevansinya dengan gangguan terhadap kesehatan sistemik, serta mekanisme perlawanan respon imun terhadap bakteri ini. Pemahaman terkait infeksi bakteri ini sangat penting dan diperlukan dalam bidang kedokteran gigi untuk mendorong tindakan pencegahan penyakit baik lokal maupun sistemik dan potensi timbulnya infeksi silang.

\section{TINJAUAN PUSTAKA}

\section{Rongga Mulut sebagai Reservoir Koloni $P$. aeruginosa}

Berbagai permukaan anatomis di rongga mulut, diantaranya gigi, mukosa oral, dan dorsum lidah merupakan lingkungan inisial bakteri $P$. aeruginosa untuk berkoloni dalam plak sebelum akhirnya dapat menginfeksi paruparu secara kronis. ${ }^{3}$ Pseudomonas aeruginosa telah lama diketahui sebagai bakteri yang berkoloni secara persisten dengan prevalensi tertinggi pada rongga mulut pasien intensive care unit (ICU) yang menggunakan ventilator. Kondisi ini meningkatkan risiko infeksi akut pada pasien imunokompromis dengan kelainan struktur paru-paru diantaranya fibrosis kistik, gangguan paru obstruktif kronis, bronkiektasis atau pneumonia melalui gangguan pertahanan epitelium dibandingkan pada pasien sehat. ${ }^{11-13}$

Transmisi $P$. aeruginosa melalui aspirasi dari saliva yang mengandung bakteri atau terfasilitasi oleh protesa gigi, DUWLs, dan alatalat medis seperti bronkoskopi, pipa endotrakeal, dan ventilator mekanis.3,8,14,15 Bakteri $P$. aeruginosa dapat berkoloni pada plak protesa gigi pasien lanjut usia walaupun dengan kebersihan rongga mulut yang baik. Hal ini menunjukkan kemungkinan sifat resistensi bakteri terhadap pembersihan mekanis dan atau kimiawi protesa. ${ }^{14}$

Pseudomonas aeruginosa mempunyai kemampuan untuk berkoloni dan membentuk biofilm pada permukaan dalam DUWLs. ${ }^{8}$ Selama menjalani perawatan dental, pasien mempunyai resiko terpapar bakteri yang terbawa melalui air yang melewati DUWLs. Melalui jalur ini maka potensi kontaminasi dapat terjadi melalui skaler ultrasonik, high speed turbine dental handpiece maupun dari sumber pasokan air yang telah terkontaminasi bakteri ini. Fenomena hidrodinamik air yang melewati DUWLs pada saat penggunaan aktif dental unit mencapai kecepatan 60$100 \mathrm{ml} /$ menit secara intermiten sepanjang hari, namun apabila dental unit tidak digunakan maka air akan mengalami stagnasi (water stagnation). Stagnasi air yang terkontaminasi bakteri memudahkan terbentuknya biofilm.8,16 American National Standard Institute/American Dental Association telah mengeluarkan rekomendasi yang digunakan sebagai standar pencegahan retraksi cairan rongga mulut kedalam dental unit, dan saat ini telah berkembang alat anti-retraksi yang telah terpasang di dental unit. Namun, efektivitasnya masih menjadi pertanyaan seiring masih banyak ditemukan kontaminasi bakteri $P$. aeruginosa dalam DUWLs yang berpotensi tinggi terhadap infeksi silang. ${ }^{17}$ Disinfeksi menggunakan hidrogen peroksida/ion silver $0,02 \%$ dengan kombinasi reverse osmosis pada air ter-deionisasi secara kontinu saat dental unit digunakan, dapat menghilangkan koloni P.aeruginosa secara total. Metode ini lebih efektif dibandingkan dengan penggunaan hidrogen peroksida/asam perasetik 0,26\% pada air ter-deionisasi 10 menit yang diikuti 
final flushing air 5 menit sebelum dental unit digunakan. ${ }^{18}$

Pseudomonas aeruginosa dan Acinetobacter spp. ditemukan lebih banyak berkoloni pada biofilm subgingiva dan saliva pasien periodontitis kronis dan/atau agresif dibandingkan pasien tanpa periodontitis., 4 Bakteri ini diketahui dapat berinteraksi dengan bakteri periodontopatik red complex dan memiliki aktivitas sinergis dengan bakteri Aggregatibacter actinomycetemcomitans, sehingga dapat meningkatkan risiko individu menderita penyakit periodontal. ${ }^{4}$

Peningkatan bakteri $P$. aeruginosa dalam biofilm poket periodontal seringkali dikaitkan dengan kondisi dysbiosis (ketidakseimbangan) mikrobiota subgingival. ${ }^{9}$ Kondisi homeostasis rongga mulut memberikan proteksi terhadap resiko berkembangnya bakteri P.aeruginosa. Proteksi tersebut diperankan oleh mikroorganisme normal (indigenous flora) yang memproteksi lingkungannya agar bakteri $P$. aeruginosa tidak berkoloni membentuk biofilm dan tetap dalam kondisi planktonik di dalam saliva. Di satu sisi kondisi $\mathrm{pH}$ rendah pada kandungan sukrosa yang tinggi menguntungkan bagi mikroorganisme normal Streptococcus spp. dan Lactobacillus spp. untuk mensekresi asam laktat sebagai produk akhir hasil fermentasi karbohidrat, namun di sisi lain dapat bersifat antibakteri untuk mereduksi jumlah bakteri P.aeruginosa. ${ }^{19}$ Apabila terjadi perubahan kondisi homeostasis, misalnya pada penggunaan antibotik berspektrum luas dalam jangka panjang, akan memengaruhi jumlah streptokokus oral sehingga menyebabkan dysbiosis. Perubahan komposisi bakteri pada kondisi periodontitis yang diikuti dengan gangguan imunologis akan mengakibatkan proporsi jumlah bakteri $P$. aeruginosa lebih tinggi dibandingkan pada kondisi jaringan periodontal sehat dan/atau imunokompeten. ${ }^{9}$

\section{Infeksi $\boldsymbol{P}$. aeruginosa di Rongga Mulut}

Infeksi $P$. aeruginosa di rongga mulut pada pasien yang mendapatkan prosedur dental dan disertai dengan status kebersihan oral yang buruk dilaporkan dapat menimbulkan aneurisma mikotik arteri karotis. ${ }^{20,21}$ Hasil penelusuran terhadap beberapa kemungkinan penyebab infeksi, mengindikasikan bahwa infeksi berasal dari air yang terkontaminasi bakteri $P$. aeruginosa dan dari reservoir bakteri biofilm pada DUWLs yang digunakan dalam prosedur dental untuk melakukan irigasi, mengurangi panas akibat instrumentasi, dan berkumur. ${ }^{22}$ Adanya akses melalui rongga mulut menyebabkan kemungkinan bakteri dapat tertelan, terinhalasi atau terinokulasi pada daerah perlukaan oral saat perawatan dental diantaranya tindakan ekstraksi gigi, perawatan endodontik, bedah periodontal, dan root planning. Perawatan dental tersebut sangat berpotensi bagi bakteri untuk berkoloni di rongga mulut dan menginfeksi organ dan sistem organ lainnya secara kronis melalui sistem pembuluh darah dan limfatik. 6,7,23 Prosedur ekstraksi gigi yang dilakukan di dental unit dengan suplai air yang terkontaminasi $P$. aeruginosa dilaporkan menyebabkan aneurisma mikotik arteri karotis. ${ }^{20}$ Selain itu, anatomi sinus paranasal pada regio oromaksilofasial memberikan akses terhadap penyebaran infeksi, seperti yang terjadi pada kasus abses otak yang juga secara bersamaan ditemukan infeksi gigi molar atas kanan. ${ }^{21}$ Walaupun bakteri ini diketahui sangat patogen pada pasien imunokompromis namun infeksi sekunder pada pasien imunokompeten juga 
dapat terjadi seperti yang dilaporkan oleh D'Ovidio $\mathrm{dkk}^{22}$, yang melaporkan kasus sinusitis maksilaris purulent akut setelah pemasangan implan dental dengan augmentasi sinus maksilaris akibat kontaminasi $P$. aeruginosa pada DUWLs pada saat melakukan prosedur kerja. Kemampuan resistensi $P$. aeruginosa terhadap antibiotik terlihat pada koloni yang masih ditemukan di periapikal sebanyak $6,8 \%$ pada gigi pasca perawatan endodontik kasus periodontitis apikalis. $^{24}$ Secara ringkas kemungkinan patogenesis infeksi $P$. aeruginosa di rongga mulut disajikan pada Gambar 1.

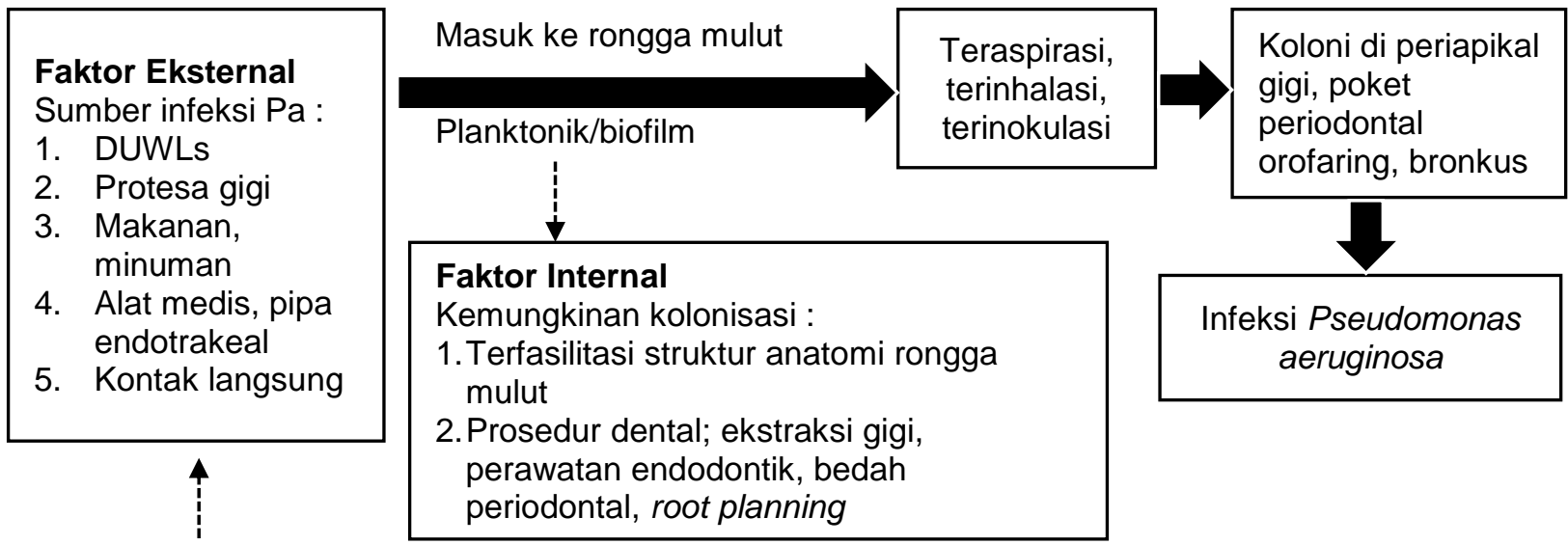

\section{Pasien \\ imunokompromis}

Gambar 1. Mekanisme Infeksi P. aeruginosa di Rongga Mulut (proposed mechanism). Pa, Pseudomonas aeruginosa. ${ }^{2,5-8,10-16,20,22-25}$

\section{Respon Imun Hospes pada Infeksi $P$. aeruginosa di Rongga Mulut}

Pseudomonas aeruginosa merupakan salah satu bakteri aerob basil Gram-negatif yang bersifat motil, laktosa negatif, berflagel polar tunggal dan memiliki pili tipe IV yang berturut-turut berfungsi untuk motilitas swimming, swarming dan twitching dalam melakukan perlekatan pada sel epitel. ${ }^{26-28}$ Bakteri ini sangat sensitif pada daerah yang kering dan dapat hidup hanya selama pada kondisi lembap dan berair. ${ }^{26}$ Pseudomonas aeruginosa menggunakan berbagai faktor virulensinya untuk memfasilitasi adhesi, invasi, dan penyebaran pada sel epitel. ${ }^{29}$ Bakteri ini memiliki lipopolisakarida (LPS); sistem sekresi tipe III (T3SS) dengan empat protein efektor, ExoS, ExoT, ExoU, dan ExoY; sistem sekresi tipe II (T2SS) diantaranya eksotoksin A, lipase, fosfolipase, alkaline phosphatase; protease; alginate; dan kemampuan membentuk biofilm. ${ }^{27,29}$ Isolat $P$.aeruginosa dari lingkungan alamiah mengekspresikan gen yang mengkode exoS, sedangkan strain dengan gen yang mengkode exoU lebih banyak ditemukan pada lingkungan buatan. ${ }^{30}$ Bakteri ini dalam biofilm mampu meningkatkan produksi TNF- $\alpha$ dan IL6 dibandingkan dengan bentuk planktoniknya pada sel monosit human. ${ }^{31}$ Pigmen pyocyanin P.aeruginosa juga mampu menginduksi apoptosis pada sel limfosit B melalui aktivasi caspase-3 yang ditunjukkan adanya fragmentasi nuklear. ${ }^{32}$

Respon imun hospes sebagai pertahanan pertama kali terhadap biofilm $P$. aeruginosa dihasilkan melalui sistem imun non spesifik. 
Respon imun ini meliputi oxidative burst, akumulasi, penetrasi, fagositosis dan eliminasi bakteri biofilm. Agregasi $P$. aeruginosa dalam biofilm dengan kepadatan tertentu akan dikelilingi oleh neutrofil yang telah teraktivasi. Aktivasi neutrofil dapat melalui kontak langsung bakteri via kompleks imun-LPS dan alginate, serta tersensitisasi oleh endotoksin dan komponen terlarut respon imun diantaranya TNF- $\alpha$, platelet-activating factor, leukotriene B4, dan interleukin-8 (IL-8). Neutrofil yang terakumulasi pada biofilm akan membutuhkan oksigen untuk proses fagositosis sehingga mengakibatkan penurunan oksigen secara cepat dan oksigen tereduksi secara molekuler menjadi superoksida (oxidative burst). ${ }^{33}$

Sel akan mengenali bentuk molekul dan sinyal bakteri (pathogen-associated molecular patterns) diantaranya komponen matriks biofilm, produk bakteri, dan bentuk planktoniknya melalui pattern recognition receptors (PRRs). Toll like receptors (TLRs) dan Nod-like receptors (NLRs) sebagai PRR permukaan dan endosomal sel, dapat ditemukan pada neutrofil dan sel epitel. ${ }^{33,34}$ TLR4 dan TLR5 berturut-turut dapat mengenali LPS dan flagellin yang selanjutnya akan menginduksi molekul transduksi sinyal intraseluler baik melalui jalur sinyal NF-kB, Sp1, p38 dan JNK yang akan mendorong transkripsi gen untuk memproduksi sitokin inflamatori IL-1, IL-6, IL-8, TNF- $\alpha$,dan faktor hospes lainnya. ${ }^{13,35-37}$ Produksi IL-6 tersebut dibutuhkan untuk mengoptimalkan infiltrasi neutrofil menuju ke area inflamasi melalui upregulation ICAM-1, priming, dan regulasi neutrofil. ${ }^{38}$ Setelah neutrofil memfagositosis bakteri planktonik akan mengalami apoptosis yang selanjutnya akan difagositosis oleh makrofag. Biofilm P. aeruginosa dalam dapat meningkatkan akumulasi molekul LPS dan DNA-nya pada matriks eksopolisakarida sehingga akan meningkatkan produksi TNF- $\alpha$, IL-6, IL12p40, PGE 2 , dan NO oleh makrofag dan neutrofil yang menyebabkan peningkatan infiltrasi sel-sel fagosit. Timbulnya reaksi hiperinflamatori ini mengakibatkan kerusakan jaringan lebih parah dan menyulitkan eradikasi bakteri. ${ }^{39}$

\section{DISKUSI}

Infeksi rongga mulut yang disebabkan $P$. aeruginosa adalah infeksi yang sangat jarang ditemukan. Bakteri ini pun bersifat patogen oportunistik yang baru dapat menimbulkan infeksi pada individu imunokompromis. ${ }^{6}$ Walaupun demikian kejadian pneumonia dan infeksi nosokomial yang disebabkan $P$. aeruginosa sangat tinggi dan dapat mengakibatkan kematian. ${ }^{1,40}$ Prevalensi pneumonia sebesar 46,9\% dilaporkan pada studi European Prevalence of Infection in Intensive Care (EPIC), sedangkan $P$. aeruginosa ditemukan $28,7 \%$ pada pasien di ICU. ${ }^{40}$ Penelitian terkait data infeksi nosokomial di Indonesia telah dilakukan namun belum ada identifikasi kultur mikroba, walaupun $P$. aeruginosa telah terdeteksi sebagai salah satu bakteri yang ditemukan pada usap lantai rumah sakit dalam hasil kajian faktor risiko infeksi nosokomial di Indonesia. ${ }^{41}$ Berbagai jalur masuk bakteri ke rongga mulut baik melalui faktor eksternal maupun internal mendorong perlunya suatu pendekatan pencegahan dan perawatan rongga mulut sebagai tata laksana dalam infeksi bakteri ini. 
Pembersihan secara mekanis dan kimiawi diperlukan untuk mencegah kolonisasi $P$. aeruginosa di rongga mulut. ${ }^{42}$ Perawatan kebersihan rongga mulut paripurna sangat diperlukan pada pasien yang berisiko tinggi seperti pasca perawatan kanker oral, dalam perawatan ICU dengan ventilator mekanis/pipa endotrakeal di rumah sakit, pasien edentulous terutama pengguna protesa gigi, dan pasien imunokompromis lainnya. ${ }^{14,42,43}$ Penggunaan sikat gigi manual atau elektrik dan foam swabs pada pasien dengan penggunaan ventilator mekanis dapat menurunkan indeks plak dental dan inflamasi gingiva. ${ }^{42}$ Plak gigi sebagai reservoir yang potensial mampu memfasilitasi $P$. aeruginosa untuk berkoloni, berproliferasi dan semakin resisten untuk dieradikasi terutama pada kebersihan rongga mulut yang buruk dan adanya infeksi periodontal. ${ }^{4}$ Namun demikian, tindakan menyikat gigi pada pasien ini juga menimbulkan komplikasi berupa terinokulasinya bakteri $P$. aeruginosa di rongga mulut, yang terdeteksi pada $17 \%$ subjek penelitian. ${ }^{44}$ Klorheksidin glukonat (CHX) sebagai agen antiseptik merupakan standar perawatan rongga mulut dalam pencegahan pneumonia bagi pasien rawat inap rumah sakit, walaupun demikian untuk mendapatkan efek yang optimal diperlukan ketepatan dalam aplikasinya. ${ }^{45}$ Aplikasi CHX 0,12\% secara topikal pada pasien trauma dengan perawatan intensif hanya menurunkan S.aureus saja namun tidak menurunkan jumlah bakteri $P$. aeruginosa. ${ }^{46} \mathrm{Di}$ satu sisi efek substantivitas (keberlanjutan efektivitas antibakteri) $\mathrm{CHX}$ dilaporkan mampu menurunkan jumlah bakteri dalam plak dibandingkan saliva karena agen kimiawi ini mampu berpenetrasi melalui struktur void dan channel dalam biofilm. ${ }^{47}$ Oleh karena itu aplikasi $\mathrm{CHX}$ dengan konsentrasi yang dianjurkan ( $\mathrm{CHX} \quad 0,2 \%$ ) sebaiknya dilakukan setelah penyikatan gigi agar dapat mengganggu kestabilan plak pada gigi dan/atau mukosa oral sehingga $\mathrm{CHX}$ mampu beradhesi lebih lama pada struktur rongga mulut sebagai pencegahan terhadap pneumonia pasca ekstubasi ventilator dan alat medis lainnya. ${ }^{42,45,47}$

Untuk mencegah kontaminasi $P$. aeruginosa dari DUWLs diperlukan protokol disinfeksi baik terhadap mikroorganisme yang masuk, di dalam, dan keluar DUWLs tanpa menyebabkan kerusakan alat-alat dental. ${ }^{7}$ Pencegahan dapat menggunakan bahan kimiawi, non-kimiawi, modifikasi alat, dan sistem DUWLS. ${ }^{17,18,48}$ Namun, prinsip kehatihatian pada prosedur dental merupakan hal utama dalam melaksanakan tindakan asepsis agar tercapai keberhasilan perawatan dental. Tindakan sederhana berupa flushing handpiece selama 5 menit sebelum memulai perawatan pasien dan 20-30 menit diantara tindakan pasien akan menurunkan jumlah bakteri dalam DUWLs. Penggunaan masker, sarung tangan, pelindung mata, dan rubber dam pada prosedur dental oleh dokter gigi dapat mencegah masuk dan keluarnya bakteri dari dental unit sehingga dapat mencegah infeksi silang. ${ }^{7}$

Melalui review ini diharapkan tenaga kesehatan dapat mengetahui bahaya infeksi yang disebabkan oleh $P$. aeruginosa di rongga mulut sehingga dapat meningkatkan kewaspadaan dalam melakukan prosedur dental, memberikan edukasi perawatan gigi dan mulut bagi pengasuh untuk pasien imunokompromis, serta melakukan monitoring berkala terhadap kontaminasi bakteri pada 
sistem air dental unit beserta alat yang digunakan.

\section{KESIMPULAN}

Infeksi $P$. aeruginosa di rongga mulut bukan merupakan kasus yang umum terjadi, namun kejadian-kejadian terkait cukup banyak dilaporkan. Rongga mulut berperan sebagai reservoir kolonisasi $P$. aeruginosa dapat menimbulkan infeksi baik di rongga mulut maupun sistem organ sistemik, terutama disertai dengan kondisi imunokompromis. Tindakan pencegahan secara komprehensif perlu dilakukan, mengingat sifat bakteri yang sangat resisten terhadap berbagai antibiotik sehingga menyulitkan eradikasi.

\section{DAFTAR PUSTAKA}

1. El-Solh AA, Pietrantoni C, Bhat A, Okada M, Zambon J, Aquilina A, et al. Colonization of Dental Plaques: A Reservoir of Respiratory Pathogens for HospitalAcquired Pneumonia in Institutionalized Elders. Chest. 2004;126(5):1575-82.

2. Heo S, Haase EM, Lesse AJ, Gill SR, Scannapieco FA. Genetic Relationships between Respiratory Pathogens Isolated from Dental Plaque and Bronchoalveolar Lavage Fluid from Patients in the Intensive Care Unit Undergoing Mechanical Ventilation. Clin Infect Dis. 2008;47(12):1562-70.

3. Caldas RR, Le Gall F, Revert K, Rault G, Virmaux M, Gouriou S, et al. Pseudomonas aeruginosa and periodontal pathogens in the oral cavity and lungs of cystic fibrosis patients: A case-control study. J Clin Microbiol. 2015;53(6):1898-907.

4. Souto R, Silva-Boghossian CM, Colombo APV. Prevalence of Pseudomonas aeruginosa and Acinetobacter spp. in subgingival biofilm and saliva of subjects with chronic periodontal infection. Brazilian J Microbiol. 2014;45(2):495-501.

5. Yip KH-K, Smales RJ. Implications of oral biofilms in medically at risk persons is. J
Biomed Res. 2012;26(1):1-7.

6. Gendron R, Grenier D, Maheu-Robert LF. The oral cavity as a reservoir of bacterial pathogens for focal infections. Microbes Infect. 2000;2(8):897-906.

7. Barbot $\mathrm{V}$, Robert $\mathrm{A}$, Rodier $\mathrm{MH}$, Imbert $\mathrm{C}$. Update on infectious risks associated with dental unit waterlines. FEMS Immunol Med Microbiol. 2012;65(2):196-204.

8. Abdouchakour F, Dupont C, Grau D, Aujoulat F, Mournetas P, Marchandin H, et al. Pseudomonas aeruginosa and Achromobacter sp. Clonal Selection Leads to Successive Waves of Contamination of Water in Dental Care. Appl Env Microbiol. 2015;81(21):7509-24.

9. Colombo APV, Magalhaes $\mathrm{CB}$, Hartenbach FARR, Souto RM do, Silva-Boghossian CM da. Periodontal-disease-associated biofilm: A reservoir for pathogens of medical importance. Microb Pathog. 2016;94:27-34.

10. Gaetti-jardim EC, Marqueti AC, Faverani LP, Júnior EG. Antimicrobial resistance of aerobes and facultative anaerobes isolated from the oral cavity. J Appl Oral Sci. 2010;18(6):551-9.

11. Scannapieco FA, Stewart EM, Mylotte JM. Colonization of dental plaque by respiratory pathogens in medical intensive care patients. Crit Care Med. 1992;20(6):740-5.

12. Tada A, Hanada N. Opportunistic respiratory pathogens in the oral cavity of the elderly. FEMS Immunol Med Microbiol. 2010;60:1-17.

13. Lin CK, Kazmierczak BI. Inflammation: a double-edged sword in the response to Pseudomonas aeruginosa infection. J Innate Immun. 2017;9(3):250-61.

14. Donnell LEO, Smith K, Williams C, Nile CJ, Lappin DF, Bradshaw D, et al. Dentures are a Reservoir for Respiratory Pathogens. J Prosthodont. 2016;25:99-104.

15. Marino PJ, Wise MP, Smith A, Marchesi $\mathrm{JR}$, Riggio MP, Lewis MAO, et al. Community analysis of dental plaque and endotracheal tube bio fi Ims from mechanically ventilated patients. J Crit Care. 2017;39:149-55.

16. Porteous N. Dental unit waterline contamination--a review. Tex Dent $\mathrm{J}$. 2010;127(7):677-85.

17. Berlutti F, Testarelli L, Vaia F, De Luca M, Dolci G. Efficacy of anti-retraction devices in preventing bacterial contamination of dental unit water lines. J Dent. 2003;31(2):105-10. 
18. Dallolio L, Scuderi A, Rini MS, Valente S, Farruggia $P$, Sabattini MAB, et al. Effect of Different Disinfection Protocols on Microbial and Biofilm Contamination of Dental Unit Waterlines in Community Dental Practices. Int J Environ Res Public Health. 2014;11:2064-76.

19. He X, Hu W, He J, Guo L, Lux R, Shi W. Community-based interference against integration of Pseudomonas aeruginosa into human salivary microbial biofilm. Mol Oral Microbiol. 2012;26(6):337-52.

20. Knouse MC, Madeira RG, Celani VJ. Pseudomonas aeruginosa causing a right carotid artery mycotic aneurysm after a dental extraction procedure. Mayo Clin Proc. 2002;77(10):1125-30.

21. Pereira RS, Bonardi JP, Ferreira ACD, Latini GL. An unusual case of dental infection by Pseudomonas aeruginosa causing a brain abscess: case report. Aust Dent J. 2017;62(4):523-7.

22. D'Ovidio C, Carnevale A, Pantaleone G, Piattelli A, Di Bonaventura G. First report of an acute purulent maxillary sinusitis caused by Pseudomonas aeruginosa secondary to dental implant placement in an immunocompetent patient. $\mathrm{Br}$ Dent $\mathrm{J}$. $2011 ; 211(5): 205-7$.

23. Vesna A. Focal Infections in Oral Cavity. $J$ Dent Oral Heal. 2018;4(2):1-2.

24. Fujii R, Saito Y, Tokura Y, K-i N, Okuda K, Characterization IK. Characterization of bacterial flora in persistent apical periodontitis lesions. Oral Microbiol Immunol. 2009;24:502-5.

25. Mena KD, Gerba CP. Risk Assessment of Pseudomonas aeruginosa in Water. Vol. 201, Reviews of Environmental Contamination and Toxicology. 2009. 1-38 hal.

26. Dahlen G. Bacterial infections of the oral mucosa. Periodontol 2000. 2009;49(1):1338.

27. Alhazmi A. Pseudomonas aeruginosa Pathogenesis and Pathogenic Mechanisms. Int J Biol. 2015;7(2):44-67.

28. Ruffin M, Brochiero E. Repair Process Impairment by Pseudomonas aeruginosa in Epithelial Tissues: Major Features and Potential Therapeutic Avenues. Front Cell Infect Microbiol. 2019;9(May):1-18.

29. Gellatly SL, Hancock REW. Pseudomonas aeruginosa: new insights into pathogenesis and host defenses. Pathog Dis. 2013;67:159-73.

30. Rutherford V, Yom K, Ozer EA, Pura O, Hughes A, Murphy R, et al. Environmental
Reservoirs for exoS+ and exoU+ strains of Pseudomonas aeruginosa. Env Microbiol Rep. 2019;10(4):485-92.

31. Ciornei CD, Novikov A, Beloin C, Fitting C, Caroff M, Ghigo J. Biofilm-forming Pseudomonas aeruginosa bacteria undergo lipopolysacharide structural modifications and induce enhanced inflammatory cytokine response in human monocytes. Innate Immun. 2010;1-15.

32. Susilowati H, Hutomo S, Siagian JW, Siwi DP. Caspase-3-dependent Cell Death in B lymphocyte Caused by Pseudomonas aeruginosa Pyocyanin. J Dent Indonesia. 2015;22(2):51-5.

33. Jensen PO, Givskov M, Bjarnsholt T, Moser C. The immune system vs Pseudomonas aeruginosa biofilms. FEMS Immunol Med Microbiol. 2010;59:292-305.

34. Lavoie E, Wangdi T, Kazmierczak B. Innate immune response to Pseudomonas aeruginosa infection. Microbes Infect. 2011;13(14-15):1133-45.

35. Zhang J, Wu X-Y, Yu F-SX. Inflammatory responses of corneal epithelial cells to Pseudomonas aeruginosa infection. Curr Eye Res. 2005;30(7):527-34.

36. Borgatti M, Bezzerri V, Mancini I, Nicolis E, Cristina M, Lampronti I, et al. Induction of IL-6 gene expression in a CF bronchial epithelial cell line by Pseudomonas aeruginosa is dependent on transcription factors belonging to the Sp1 superfamily.Biochem Biophys Res Commun.2007;357:977-83.

37. Pier GB. Pseudomonas aeruginosa lipopolysaccharide: A major virulence factor, initiator of inflammation and target for effective immunity. J Med Microbiol. 2007;297:277-95.

38. Cole N, Bao S, Willcox M, Husband AJ. Expression of interleukin- 6 in the cornea in response to infection with different strains of Pseudomonas aeruginosa. Infect Immun. 1999;67(5):2497-502.

39. Ciszek-Lenda M, Strus M, Walczewska G, Majka A, Machul-Żwirbla A, Mikolajczyk D, et al. Pseudomonas aeruginosa biofilm is a potent inducer of phagocyte hyperinflammation. Inflamm Res. 2019;68(5):397-413.

40. Vincent JL, Bihari DJ, Suter PM, Bruining $\mathrm{HA}$, White J, Nicolas Chanoin $\mathrm{MH}$, et al. The Prevalence of Nosocomial Infection in Intensive Care Units in Europe: Results of the European Prevalence of Infection in Intensive Care (EPIC) Study. JAMA J Am Med Assoc. 1995;274(8):639-44. 
41. Balai Besar Teknik Kesehatan Lingkungan dan Pengendalian Penyakit Yogyakarta. Rencana Aksi Kegiatan BBTKLP Yogyakarta tahun 2015-2019 [Internet]. Yogyakarta; 2018. 5 hal. Tersedia pada: https://www.btkljogja.or.id/uploads/201809/rak-bbtklpp-yk-2015-2019.pdf

42. Marino PJ, Hannigan A, Haywood S, Cole $\mathrm{JM}$, Palmer $\mathrm{N}$, Emanuel $\mathrm{C}$, et al. Comparison of foam swabs and toothbrushes as oral hygiene interventions in mechanically ventilated patients: a randomised split mouth study. BMJ Open Respir Res. 2016;3:1-10.

43. Pan J, Zhao J, Jiang N. Oral cavity infection: An adverse effect after the treatment of oral cancer in aged individuals. J Appl Oral Sci. 2014;22(4):261-7.

44. Jones DJ, Munro CL, Grap MJ, Kitten T, Edmond M. Oral care and bacterimia risk in mechanically ventilated adults. Hear Lung. 2011;39(6):1-15.

45. Klompas M, Speck K, Howell MD, Greene LR, Berenholtz SM. Reappraisal of routine oral care with chlorhexidine gluconate for patients receiving mechanical ventilation: Systematic review and meta-analysis. JAMA Intern Med. 2014;174(5):751-61.

46. Scannapieco FA, Yu J, Raghavendran K, Vacanti A, Owens SI, Wood K, et al. A randomized trial of chlorhexidine gluconate on oral bacterial pathogens in mechanically ventilated patients. Crit Care. 2009;13(4):1-12.

47. García-Caballero L, Quintas V, PradaLópez I, Seoane J, Donos N, Tomás I. Chlorhexidine substantivity on salivary flora and plaque-like biofilm: An In situ model. PLoS One. 2013;8(12):1-10.

48. Lizzadro J, Mazzotta M, Girolamini L, Dormi A, Pellati T, Cristino S. Comparison between Two Types of Dental Unit Waterlines: How Evaluation of Microbiological Contamination Can Support Risk Containment. Int J Environ Res Public Health. 2019;16(328):1-14. 